\title{
Sustainable Tourism Development under the Beautiful Rural Background A Case Study of Ancient Villages Planning as Conservation
}

\author{
Lei Li, Ning Wang, Zheng Shi \\ Urban and Rural Planning, \\ Agricultural University of Hebei, \\ Baoding, 071001, China
}

\begin{abstract}
Under the guidance of the beautiful rural and the construction of ecological civilization, sustainable tourism development is bound to become a major trend in the development of tourism. As we all know, tourism has a dual nature, on the one hand, tourism can contribute to the socioeconomic and cultural development, on the other hand, it exacerbated the loss of the environment and the disappearance of local characteristics, so Sustainable tourism must be developed. Sustainable tourism is a form which combined ecological civilization and traditional form of tourism. This paper, through the planning of new WangNao Village, Shahe City as a case shows the application of sustainable tourism development to explore the theory of beautiful rural and sustainable tourism, as well as practical significance.
\end{abstract}

Keywords- beautiful rural; sustainable tourism; protection and development of ancient villages

\section{BACKGROUND OF THE BEAUTIFUL RURAL AREA}

\section{A. "Beautiful rural" under the background of new rural} construction

Beautiful rural, under the guidance of sustainable development, puts the rural construction and industry development blend together, put the farmers' income with people's livelihood improvement to make it more beautiful development. At the same time of the beautiful rural development and construction, advocating the beauty of nature, developing the modern beauty, attaching great importance to personalized beauty, planning the integral harmony, the rural develop to new rural that country and country is beautiful, family and family is affluence, here and there is harmony, everyone is happy. The rural develop to new rural that the social is harmonious, life is happiness and the environment is elegant. All the rural get together to present beautiful countryside landscape that every rural has different taste, rhythm and sight.

\section{B. Practice and development of the "beautiful rural"}

Under the new concept of the "Beautiful China", "Beautiful Rural" gets the substantial practice. It greatly promoted the development of the rural industry science , increased the farmers' income, improved the farmers' production and living conditions and speeded up the construction of ecological civilization and the new rural. A group of Famous Historic and Cultural Villages got effective protection and utilization, a group of villages which have strong agrestic colour and local characteristics cultivate and build rapidly.

\section{ANALYSIS OF SUSTAINABLE TOURISM DEVELOPMENT}

\section{A. Demand for sustainable tourism development}

With the progress and development of society, the expansion and desires of human needs, the traditional way of mass tourism is undoubtedly a huge destruction and challenge on the social, economic and environmental, especially for ancient village tourist impact. Traditional ancient village level of tourism development, resource utilization, industrial management, cultural heritage and environmental protection is not high, which is seriously affect the protection for ancient villages. Under the background of beautiful countryside, sustainable tourism development has become to the first choice on ancient village tourism development and protection.

\section{B. Definition of sustainable tourism development}

The essence of sustainable tourism development is to making the tourism and natural, cultural and human environment as a whole. Tourism development must be based on the capacity of the ecological environment, accord to local economic development and social ethics, all alternative tourism development programs must help to improve people's living standards, strengthen the linkages between culture and society and have a positive impact.

\section{Significance of sustainable tourism development}

Deterioration of the global ecological environment caused widespread concern and the reflection on the traditional mass tourism approach. With the enhancement of human environment conscious, tourism markets have changed accordingly for tourism perception, expectations, attitudes and values orientation. To achieve sustainable tourism development is to promote the transformation of social development model, the transform is from the traditional model which rely on resource consumption to promoting economic growth to new model of low-energy and high-yield, in order to achieve sustainable development harmony between the resources of natural and cultural and the environment. 


\section{PRACTICAL APPLICATION OF SUSTAINABLE TOURISM DEVELOPMENT—TAKING AN ANCIENT VILLAGE OF WANGNAO VILLAGE AS AN EXAMPLE}

\section{A. National Historical and Cultural Village-Wang Nao village}

In March 2014 ,Ministry of Housing and UrbanRural Development announced the list of the sixth group of National Historical and Cultural Town(Village),WangNao Village, ShaHe City, HeBei Province won the laurel of National Historical and Cultural Village. WangNao village has a long history, It is currently one of the best preserved ancient building community, and it has important reference value on historical research, scientific research and art appreciation.

\section{B. An ancient village-overview of Wang Nao village}

WangNao is a tourist ancient village which has 830 people and the area of $20 \mathrm{~km}^{2}$. It is located in the east of Taihang Mountain and surrounded by mountains, the terrain is hidden, it has beautiful environment and beautiful scenery. There are lots of mountains and caves, for example, BiJia Mountain, HongFeng Mountain, BaiYun Cave, JinNiu Cave and WuDi Cave, it is very rich in tourist natural resources. There are well-preserved ancient streets in the village, the original - stone - buildings blend with the architectural style of the north and south as well as the techniques of brick, tile carving, stone carving, painting, all of these are unique.

The era's progressive accelerated the decline of the village. The road is narrow and shabby, the house is old and dilapidated, old houses and new houses are uncoordinated, the lifestyle has changed, all of these are hindering the development of local tourism. The protection and development of ancient villages is imminent.

\section{Protection of the ancient village and tourist development}

WangNao village is one of the most well-preserved ancient building complex, it is at the same time that it won the laurel of National Historical and Cultural Village, The immediate problem is to speed up the protection of ancient villages. To meet the requirements of plan and protect for the ancient village, the residents moved out of the core protected areas, but the original village has no land to build, so it is only to select homestead outside the village, at last, the land on the east side of Wen Jiayuan will be built the new WangNao village, it is an important measure to protect and develop ancient villages. The tourist types and characteristics can be seen from Table I.

TABLE I. THE TOURIST TYPES AND CHARACTERISTICS OF WANG NAO VILLAGE

\begin{tabular}{|c|c|c|c|c|}
\hline $\begin{array}{l}\text { Types } \\
\text { landscape }\end{array}$ & Name of landscape & The main features & Tourist market & $\begin{array}{l}\text { Tourist } \\
\text { purposes }\end{array}$ \\
\hline $\begin{array}{l}\text { Natural } \\
\text { Landscapes }\end{array}$ & $\begin{array}{l}\text { Bijia mountain, } \\
\text { Guanyin mountain, } \\
\text { Baiyun cave, } \\
\text { Wudi cave, }\end{array}$ & $\begin{array}{l}\text { Beautiful environment, charming } \\
\text { scenery, } \\
\text { strong appreciating }\end{array}$ & $\begin{array}{l}\text { External visitors, } \\
\text { People who live in city for a } \\
\text { long time. }\end{array}$ & $\begin{array}{l}\text { Leisure entertainment, } \\
\text { Appreciation, } \\
\text { Vacation, enjoyment. }\end{array}$ \\
\hline $\begin{array}{l}\text { Human } \\
\text { landscape }\end{array}$ & $\begin{array}{l}\text { Fengluan temple } \\
\text { KangRi } \\
\text { stations,WangNao } \\
\text { villages }\end{array}$ & $\begin{array}{l}\text { Educational strong, } \\
\text { Historical research value }\end{array}$ & $\begin{array}{l}\text { Tourists to the scenic area and } \\
\text { residents around the village }\end{array}$ & $\begin{array}{l}\text { Researching, } \\
\text { Visiting, } \\
\text { education, } \\
\text { appreciation }\end{array}$ \\
\hline $\begin{array}{l}\text { intangible } \\
\text { cultural heritage }\end{array}$ & $\begin{array}{l}\text { Traditional folk culture of } \\
\text { handmade, weaving embroidery, } \\
\text { paper cutting and local operas }\end{array}$ & $\begin{array}{l}\text { local characteristics } \\
\text { is strong and highly transmissible }\end{array}$ & $\begin{array}{l}\text { Visitors have some art } \\
\text { appreciation }\end{array}$ & $\begin{array}{l}\text { Appreciation, shopping, } \\
\text { Commemorative }\end{array}$ \\
\hline
\end{tabular}

D. Sustainable tourism development and beyond for new Wang Nao village

In view of the concept of sustainable tourism development, WangNao village put the old WangNao village as the core and rely on the old WangNao village, it closely puts the improvement of the living conditions of farmers and farmers' income together and puts the local culture into the tourism, develop folk art, handmade and cultural experience into the tourism, the old and the new will weave a ancient and beautiful story together.

i) Development of traditional commerce"shopping"

The planning of new village combined with local food and craft goods, It will construct a tourist business street, restore weaving, embroidery, paper cutting and other handicraft workshop, develop distinctive cultural products, process local distinctive foods, integrate agricultural products which represent the safety, health and nutrition into tourism development. Shopping and catering become one part of the tourism environment.

ii) Inheritance of architectural features___ "housing"

To meet the requirements of rural tourism development, the new folk house have modern atmosphere and the style of old village, besides, it can be used to received tourist. So, the folk house have function of living and tourism. the residence have different types, such as townhouse, single-family villas and mid-rise building, the group of buildings are flexible. 
Architectural color is united, the primary color of public buildings is red, the residence is yellow. They are combined with locally produced red stone. The style of residence retained the architectural elements of WangNao village, for example, the form of the roof, green and red stone in the architecture and the hollow carving at top of the wall. As can be seen from picture1, picture2 and picture3.

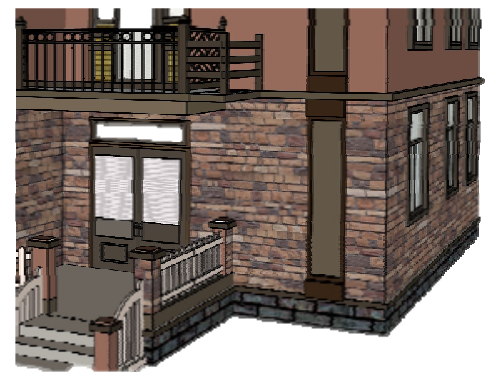

Picture 1. The application of red stone

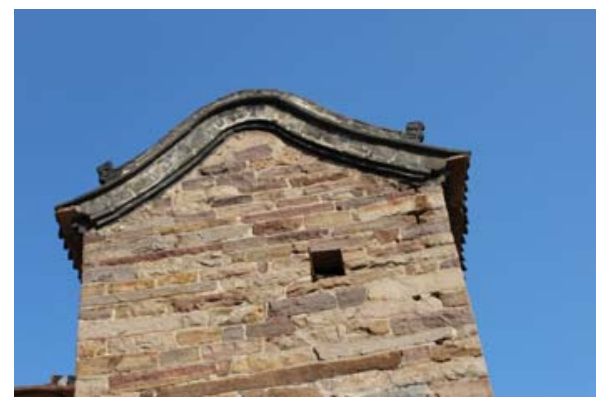

Picture 2. Roof of old WangNao village

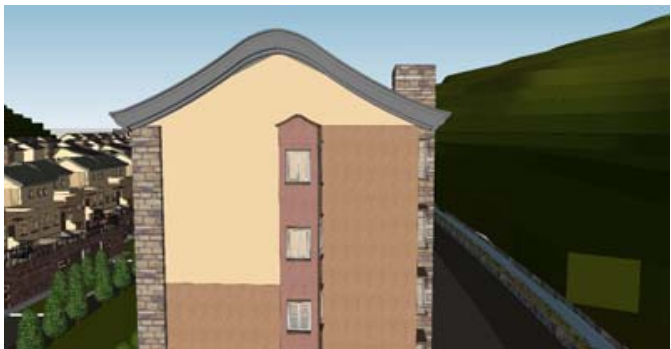

Picture 3. Roof of new WangNao village

iii) Tourist road suitable platform_—_traveling"

The terrain of new WangNao village is divided into six blocks, everyone is higher than another from east to west. The main village carriageway planning dealers around the entire village. Secondary trunk and trunk roads are related closely, the secondary roads assist the trunk road, they are consisted of the village road system. pedestrians road is 1.5 meter wide, it link residence and landscape, it is the major tourist road.

To enhance traffic safety, roundabout was constructed in roadway, at the same time, it can be regarded as landscape, topographic altitude was handled by ramps. Slope was located along the pedestrians road. To strengthen the local characteristics, main material of slope used local bluestone. Retaining wall was constructed between the road and other land, parterre was built depend on retaining wall.

iv) Enhancement of the geographical landscape"tourism"

Landscape Park and Terraced Park are not only the primary scenery, but also the important place for tourism.

The land of the Landscape Park should not construct residence, the main reason is that it is located in the tuyere of mountains. The plan combined the topography, the construction of the landscape, such as the hill (keep out wind), waterfront corridor (ranked flash floods and rain) and rock cultural landscape, reflect the modern tourist of WangNAO village.

The original site of the Terraced Park is cemetery, the cemetery was repaired and used to construct terraced natural scenery, the chess was built in the park and meet human's requirements for traditional culture, it is landscape which put entertainment and appreciation. 4

The green landscape analysis can be seen from picture

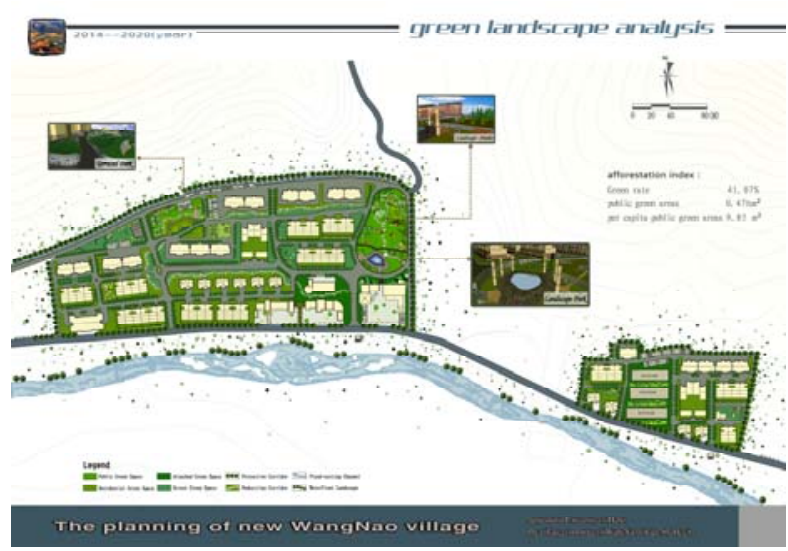

Picture 4 The green landscape analysis

vi) Applications of materials and technology"showing"

On the basis of traditional building materials and processing technology, the planning and construction combined with the actual, use solar energy, biogas and natural gas, sustainable development was putted into the construction.

The application of the double glazing: building windows with double glass are full use of locally produced building materials - glass, each layer of insulating glass windows are used to enhance the performance of indoor temperature, insulation and noise reduction.

Water loop heat pump system: it is decentralized air system which use residual heat within the building. heat loss outside can be compensated by residual heat within the building, thus maximize the system's energy — saving potential. 


\section{CONCLUSIONS}

Our country is an agricultural country with five thousand years of Chinese civilization, it has vast territory, beautiful natural landscape and rural folk culture, so the development of sustainable tourism has a great potential and promising prospects in our country.

The planning and construction of new WangNao village rely on the tourism advantages of National Historical and Cultural Village, the architectural features of ancient village was preserved, geomorphological features of the mesa was combined, the local building materials was be taken, the technology of modern energy was used, historical culture combine with the tourism. At the same time of adapting living material and spiritual demands, the construction of new village, the protection of old village, all of these accelerate sustainable development, promote the rapid development of sustainable tourism of WangNao village in Tai - hang Mountains.

\section{REFERENCES}

[1] Li Tian-Yuan, The research of Chinese tourist sustainable development [M].Nankai University Press, 2004.

[2] Lu Song, etc. Exploration and analysis of World Heritage ancient Hongcun Village. Exploration of Economic Issues, 2007(6).

[3] Zou Lin-Fang. Research and discussion related on the ancient village heritage protection and tourism development. Technology Information,2007.

[4] He Jing-Ming.Research and comment of Foreign Rural Tourism. Tourism Tribune,2003(1).

[5] Wang Guo-Dong, Lin Zhi-Yong,Chinese beautiful rural_-An Ji. The Net of YueYang,2012.

[6] Zhao Hong-Zhu, Accelerating construction of beautiful rural. Intraday ZheJiang,2010. 